Article

\title{
Subjugation, Immanent Critique, and Cruz: Adorno on Aesthetics and the Possibility of Emancipation
}

Raniel SM. Reyes

\begin{abstract}
Due to reason's instrumentalization, the Enlightenment project turned into a myth of domination instead of freeing humanity from barbarism. This dialectic of Enlightenment, as the critical theorists Theodor Adorno and Max Horkkeimer put it, destroyed our mimetic relation with nature and privileged the language of modern science and logical positivism over art, among other maladies, philosophical or otherwise. This predicament intensified upon the culture industry's supremacy in the contemporary period that converted the artwork into a commodified product, and numbed the people's critical acumen. Contra these marginalizations, I elucidate in this paper art's material configurations and liberating potentials. In connection to this, I expound art's critico-dialectical import, with a specific thrust to Mideo Cruz's controversial installations at the Cultural Center of the Philippines last 2012. Significantly, upon art's disclosure of the damaged life, Adorno claims, it can confront identity and immanently critique advanced capitalism for the fashioning of emancipatory possibilities. After constructing the building-blocks of a new aesthetic theory, I explain in the last part the lessons that philosophy can learn from art.
\end{abstract}

Keywords: Adorno, Cruz, culture industry, emancipation

Hostility to art is also hostility to the new, the unforeseen. Robert Bresson, Notes on the Cinematographer

The only philosophy which can be responsibly practiced in face of despair is the attempt to contemplate all things as they would present themselves from the standpoint of redemption.

- $\quad$ Theodor Adorno, Minima Moralia 


\section{Art in the Age of Capitalist Machinery}

The "culture industry" is advanced capitalism's contemporary face.
This term is appropriated by Adorno to denote the corrosion of high
culture into spectacle and consumerism. He opines:

The culture industry intentionally integrates its consumers from above. To the detriment of both, it forces together the spheres of high and low art, separated for thousands of years. The seriousness of high art is destroyed in speculation about its efficacy; the seriousness of the lower perishes with the civilizational constraints imposed on the rebellious resistance inherent within it as long as social control was not yet total. Thus, although the culture industry undeniably speculates on the conscious and unconscious state of the millions towards which it is directed, the masses are not primary, but secondary, they are an object of calculation, an appendage of the machinery. The customer is not king, as the culture industry would have us believe, not its subject but its object. ${ }^{1}$

This advanced type of capitalism commodifies cultural values and relations in a rationally-administered way. This is made possible by the complex collaboration of capitalism, mass media, and technology. In this context, the link between individuals, objects, and principles, assume a thinglike status. It does not only debase the value of relations and its surrounding objects, but also engenders the flagging of the individual's critical acuity.

Adorno's diagnostic appraisal of the culture industry is likewise a barefaced analysis on how capitalism bastardizes a specific aspect of culture-art. In the contemporary playing field, the particularity of the artwork is assimilated by the grammar of the culture industry, thereby becoming a pathetic prey to capitalist ideology. As it transforms into consumerist product, art's cognitiveredemptive force is obliterated in exchange of profit-generation viz. entrepreneurial gain. The dialectical potentialities inherent in the art are thereby estranged and are being converted to no less than an item of exchange-value. ${ }^{2}$ In the Dialectic of Enlightenment, Adorno explicates that the culture industry:

${ }^{1}$ Theodor Adorno, The Culture Industry (London: Routledge, 2001), 108.

2 Simon Jarvis, Adorno: A Critical Introduction (Cambridge: Polity Press, 1998), 74.

(c) 2014 Raniel SM. Reyes

http://www.kritike.org/journal/issue 14/reyes june2014.pdf

ISSN 1908-7330

$(\mathrm{cc}) \mathrm{BY}-\mathrm{NC}$ 
...generates a world of false specificity in which the advertised uniqueness of the individual product-the distinctive individual voice of a new poet, the inimitable style of a star conductor, of the sheer personality of a chat-show host-needs to be foregrounded by the relentless sameness of a whole range of the product's other qualities, from diction to typeface."3

The creative ruse of the capitalist society is managed by a group of professional tacticians who use advertisements, among others, in manipulating collective psyche.

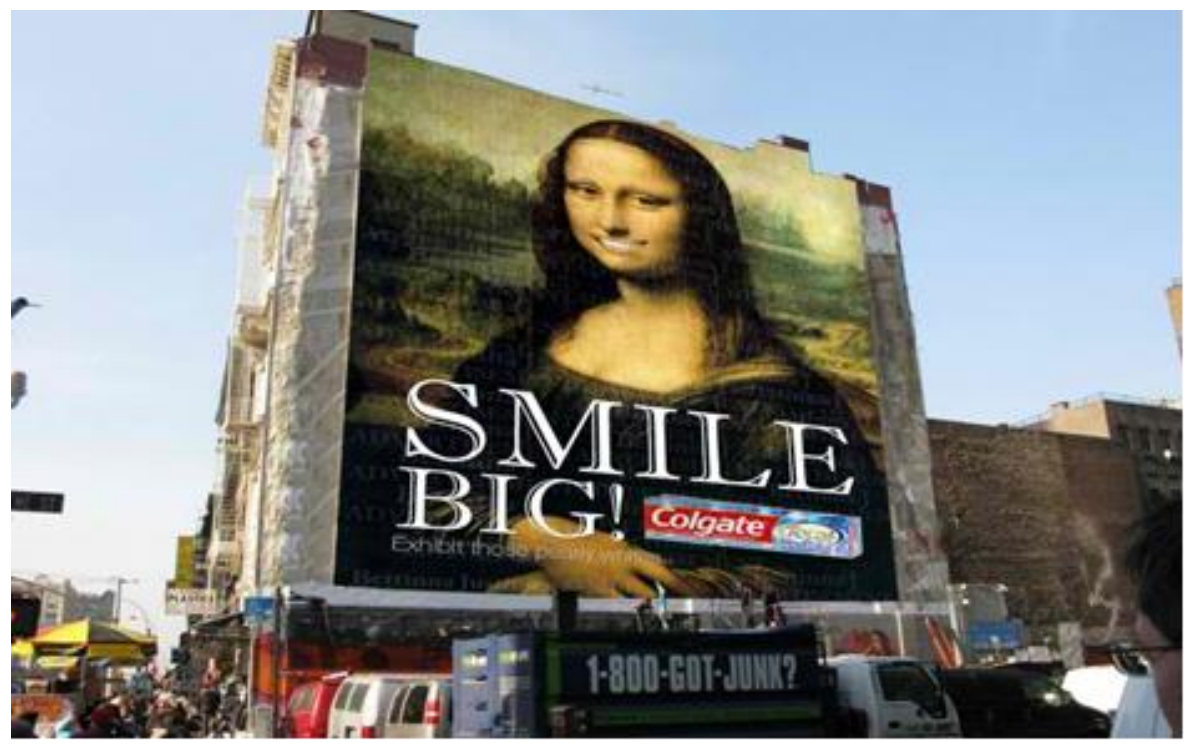

Figure 1: Colgate advertisement, "Smile Big! Exhibit those pearly whites."4

The culture industry's success via these advertisements renders the "compulsive mimesis of cultural commodification by consumers who at the same time see through them." 5 The illusions via these aesthetic facades become reproducible. Walter Benjamin has an interesting point; he thinks that the rise of advanced capitalism was pushed to the limit with its intricate integration with technology. As such, the mass mechanical reproduction of artworks (in film and photography) led to the death of the aura or the auratic

3 Theodor Adorno and Max Horkheimer, Dialectic of Enlightenment, trans. by John Cumming (London: Verso, 1997), 123.

${ }^{4}$ Digital Image, 450 x 225, <http://www.coroflot.com/bettinna/Advertising1>, 12 April 2007.

${ }^{5}$ Ibid., 167.

(c) 2014 Raniel SM. Reyes

http://www.kritike.org/journal/issue 14/reyes june2014.pdf

ISSN 1908-7330 


\section{ADORNO ON AESTHETICS}

quality of art. Its aftermath is the ghastly transfiguration of art's nature-the numbing of art's critical nature and our critical relation to it. ${ }^{6}$

The aesthetico-critical import of music, for instance, has become anathema to listeners because music has become mere commodity. ${ }^{7}$ The critical reception or even the technical appreciation of a musical item has become only secondary to purchasing it. Within the culture industry, musicians stop being artists and they are regarded as "entertainers" or "performers" whose value depends on ratings. They are massively overshadowed by pop artists who promote hilarity and even commodification of the body, rather than aesthetic dexterity and cultural rumination. ${ }^{8}$ In effect, they are alienated from their own crafts.

The capitalists do not care about aesthetic experience and the historical relevance of past events. Behind the vista of their so-called promotion of cultural values is the omnipresent face of money and that of art's massproduction. In fact, the reception is not really directed for all, but only for the few who can buy it. Hence, appreciation and labor are blurred for financial gains. In this period, the desire is not anymore to appreciate artworks, but to regard them as items of consumption. In fact, one can only purchase a capitalist item when money is at hand-tantamount to allowing oneself to be exploited by the culture industry. After acquiring a product, one can enjoy it naively. Beyond the experience of amusement, one does not anymore enjoy the depth of the artistic rendition. Rather, he/she only relishes the feeling of bearing the fruits of one's labor, which is still part of the pre-fabricated ploy employed by the capitalist strategists. Therefore, for the said system to maintain its authoritarian machinery, it must continue to generate reified spectacles, like the aforementioned circumstance, in order to prevent critical reaction from the consumers.

${ }^{6}$ Cf. Walter Benjamin, "The Work of Art in the Age of Mechanical Reproduction," in Illuminations: Essays and Reflections, trans. by Harry Zohn and ed. by Hannah Arendt (New York: Schocken Books, 2007), 217-252.

${ }^{7}$ Adorno, The Culture Industry, 46.

${ }^{8}$ What aggravates this predicament is the fact that some showbiz personalities and commercial models who cannot even carry a single note are the foremost singers in the country. This is the reason why the concerts of Filipino comedians like Vice Ganda and Manny Pukyaw, as well as sexy actress Anne Curtis, produce more profit than that of profound cultural singers of the likes of Joey Ayala, Garry Granada, and Cynthia Alexander. Well, Alexander already went to the West for lack of local appreciation. Even the dance craze of the Filipina actress Marian Rivera and the global phenomenon Gangnam style more forcefully define the art of dancing at present, than do historically and culturally-oriented dance groups. Actually, the end of the world myth behind Psy's horse-like moves could mean art's miscarriage, the Korean way.

(c) 2014 Raniel SM. Reyes

http://www.kritike.org/journal/issue 14/reyes june2014.pdf

ISSN 1908-7330

$(\mathrm{cc}) \mathrm{BY}-\mathrm{NC}$ 


\section{Art's Immanent Configuration and Mideo Cruz's Untimely Arrival}

\section{The Material Dynamics of the Artwork}

Philosophy against the backdrop of the Enlightenment tradition ponders art with subsidiary value. Art's subordinated status is basically founded on the modern privileging of the claims of positivist metaphysics, thereby splitting it from the language of science. In order to advance a comprehensive resistance against this epistemological prejudice, Adorno formulates his book, Aesthetic Theory, as his wrecking ball to embattle rationality's revulsion towards exteriority and art. The radical force behind this endeavor attempts to formulate a new "philosophy of art" contrary to modernity's conception of aesthetics or art history which is grounded on blind metaphysical theories and anatomized experiences. In the eyes of Adorno, this brand of aesthetics, "tends to reduce works of art to the role of a series of examples of its own general tenets. It thereby misses what is unique in any individual artwork; misses, indeed, just what makes it a work of art." ${ }^{9}$

In opposition to this predominant Enlightenment reduction of art into the domains of ornamental design, Adorno contends that art has a truthcontent and has the capability of overcoming the logic of representation of which traditional art is a victim. His reformulated philosophy of art, as I would call it, is "something that has escaped reality and is nevertheless permeated with it...it vibrates between this seriousness and lightheartedness. It is this tension that constitutes art."10 In furthering this counter-discourse, Adorno elucidates art's constitution by characterizing it as materially grounded. It is then valid to claim that the nature of art is not a given reality, like the Cartesian cogito of modern philosophy. In other words, it still necessitates socio-historical struggles and is subjected to the provisional features of life that henceforth condition the possibility of its cultural production and function. Thus, an artwork has immanent dynamics and sociality. In the case of a painting, its canvass can be understood as the canvass of a society:

Aesthetics is under no obligation to deduce the objectivity of its historical content in historicizing fashion, as being the inevitable result of the course of history; rather, this objectivity is to be grasped according to the form of that historical content. It is not, as the trivial paradigm would have it, that aesthetics moves

${ }^{9}$ Jarvis, Adorno: A Critical Introduction, 90.

${ }^{10}$ Theodor Adorno, Notes to Literature, vol. II, trans. by Shierry Weber (New York: Columbia University Press, 1991), 249.

(c) 2014 Raniel SM. Reyes

http://www.kritike.org/journal/issue 14/reyes june2014.pdf

ISSN 1908-7330

$(\mathrm{cc})$ BY-NC 
and is transformed in history: History is immanent to the truth content of aesthetics. ${ }^{11}$

The historical meaning of art rests on the intrinsic truth that is itself historically conditioned. Its truth-content is a crystallization of history that thereby constitutes its historical meaning. ${ }^{12}$ In addition, art's content assumes a historical value via the objectivation of correct consciousness in the artwork or is warranted by the historical substance of its time. ${ }^{13}$ In this vein, artists must be faithful to the virtue of openness and the value of material rootedness, and not to modern essentialist theorizations. For example, the soil painting craft practiced in the Talaandig School of Living Tradition in Bukidnon, Philippines depicts the people's ethical reverence to the world and its animate and inanimate affects. The Talaandigs (the indigenous people) believe that the land does not only serve as a ground of their existence, but also as a medium both for the preservation and cultivation of their lofty tradition.

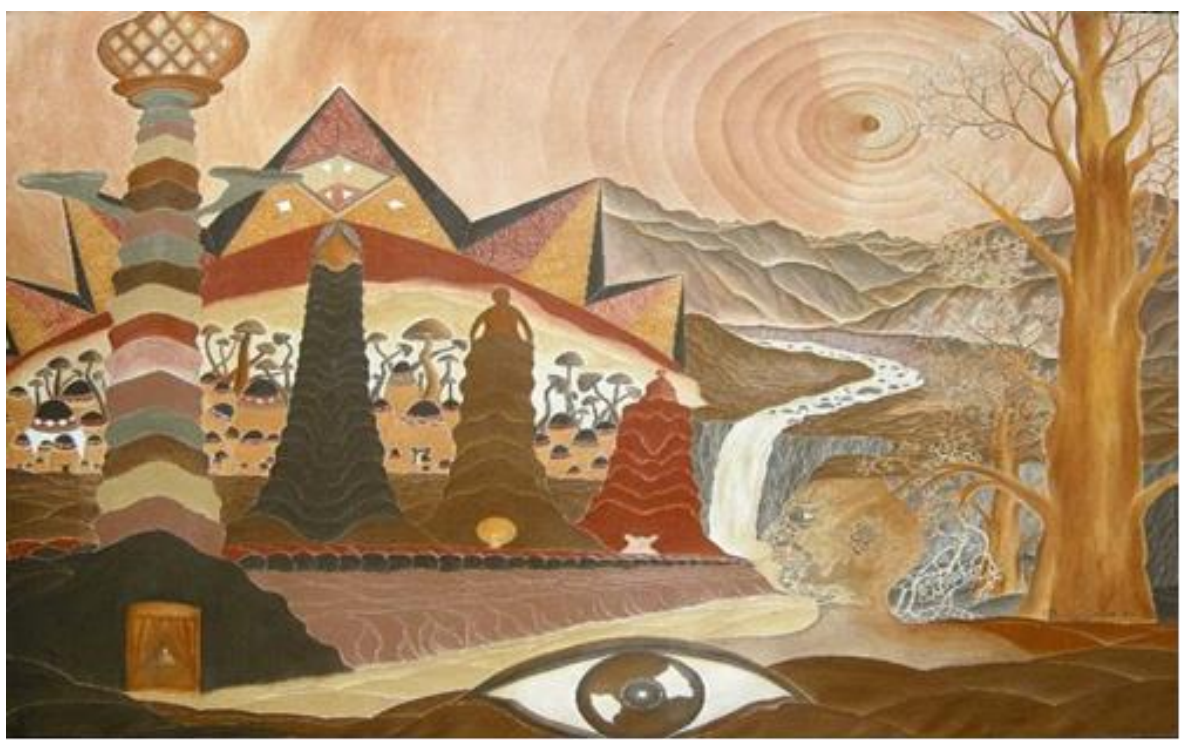

Figure 2: "The Unseen World" by Marcelino Necosia, Jr. ${ }^{14}$

11 Theodor Adorno, Aesthetic Theory, trans. by Robert Hullot-Kentor (London: Continuum, 2004), 357.

12 Cf. Lambert Zuidervaart, Adorno's Aesthetic Theory (Cambridge: Massachusetts Institute of Technology Press, 1994), 43.

${ }^{13}$ Adorno, Aesthetic Theory, 251.

${ }^{14}$ Digital Image. Soil on canvass, in Talaandig School of Living Tradition Soil Paintings, <http://www.facebook.com/photo.php?fbid=166653023354019>, 22 April 2007.

(c) 2014 Raniel SM. Reyes

http://www.kritike.org/journal/issue 14/reyes june2014.pdf

ISSN 1908-7330

\section{(cc) BY-NC}


Being historical, art's conceptual constellations are always in-themaking, hence, enabling it to be elusive from any underlying identitarian principle. Inasmuch as art is a socio-historical product, it only points that its external and internal development is dialectical. According to Adorno, "If the artwork is nothing fixed in itself, but something in motion, then its immanent temporality is communicated to its parts and whole in such a fashion that their relation develops in time and that they are capable of cancelling this relation. If artworks are alive in history by virtue of their own processual character, they are also able to perish in it." 15

Adorno extends his radical vindication of art versus the Enlightenment project as a form of enduring radicalism against the culture industry principally for downgrading art by delimiting its value in the ambit of exchange-value. Albeit an artwork is inexorably material viz. historical, its excessive monumentalization would engender its banalization and would be a terrific opportunity for advanced capitalism to penetrate its creatively protean corpus. An archetypal instance happened in the Philippines, when the differential and democratic values behind 1986 EDSA People Power revolution were merely reduced to market goods, in the likes of yellow apparels, caps, watches, etc. Desolately, the exuberant force of the people's collective pursuit for freedom and deliberative participation, among others, has been diminished, if not disposed in the dustbin of Philippine political history. And their involvement in the event's yearly commemoration has only become tantamount to wearing these capitalist-manipulated items, thereby numbing their historical cognizance for the continuation of the revolution's ethico-emancipatory vigor.

\section{Adorno's Negative Aesthetics as a Social Critique}

Reality is filled with variegated social experiences and antagonisms, whose dialectical oppositions are constitutive of its unity and pre-condition the cultivation of historical transformations. Contradictions emerge from the scene when reason becomes debilitated to give a unifying account to these various experiences. This is so when something has glided to the rational coalescing net that thereby constitutes the non-identical. In the words of J.M. Bernstein, "the experience of contradiction becomes the experience of an object claiming its unifying concept; my experience of that claim is . . my experience, my dawning recognition, that I could not have rationally dominated the item in the first place without its claiming - a claiming, again, which only appears as reason fails." 16

\footnotetext{
${ }^{15}$ Ibid., 235.

${ }^{16}$ J.M. Bernstein, "Negative Dialectics as Fate: Adorno and Hegel," in Thomas Huhn ed., The Cambridge Companion to Adorno (Cambridge: Cambridge University Press, 2004), 36.

(c) 2014 Raniel SM. Reyes

http://www.kritike.org/journal/issue 14/reyes june2014.pdf

ISSN 1908-7330 


\section{ADORNO ON AESTHETICS}

These contradictory struggles when reflectively raised into the level of the concept forms Adorno's negative dialectics. This dialectic is in the first place negative because "it is riveted to the moment in which the object appears as 'more' that what its covering concept has claimed it is." 17 Also, this kind of thinking is repugnant to any underlying essentialist or teleological reconciliation of reality's polar opposites. He opines:

Contradiction is the non-identity under the aspect of identity; the dialectical primacy of the principles of contradiction makes the thought of unity the measure of heterogeneity. As it collides with its limit, it exceeds itself. Dialectics is the consequent consciousness of nonidentity. It does not begin by taking a standpoint. Dialectics mediates critically on itself, reflects on its own movements. Such a dialectic is negative. ${ }^{18}$

From the vantage point of negative dialectics, the artwork develops into a dialectical site for the antagonism between the necessity of universal concepts in art creation, and the need to give ears to the particulars. ${ }^{19}$ However, this tension transcends the traditional frame given to us by logic because this kind of dialectical aesthetics is a globular movement between the particular and universal without any fixed generalizations. As Adorno explains, "If aesthetics is to avoid the extremes of positing prescription alien to art on the one hand, and inconsequential classification of empirical data on the other, it must be dialectical . . . one could define dialectical method as an endeavor to overcome the rift between deduction and induction so prevalent in reified thought." 20

Based from the above explanation, we can derive a new philosophy of art or dialectical aesthetics proficient in ardently attempting to hoist art's unconscious relations and struggles between the universal and particular into the conscious level. Here, the universal does not assimilate the particular into its epistemological categories, "but from the dynamic of particularities themselves." ${ }^{21}$ But as a caveat, this antagonism is not just a cultural concern or simply, according to Lambert Zuidervaart, "a matter of philosophical arguments, nor is it simply a tension within art: it permeates all of advanced

17 Ibid., 37.

18 Theodor Adorno, Negative Dialectics, trans. by E. B. Ashton (London: Routledge, 1973), 145.

${ }^{19}$ Cf. Zuidervaart, Adorno's Aesthetic Theory, 49.

${ }^{20}$ Adorno, Aesthetic Theory, 510.

${ }^{21} \mathrm{Ibid} ., 270$.

(c) 2014 Raniel SM. Reyes

http://www.kritike.org/journal/issue 14/reyes june2014.pdf

ISSN 1908-7330

(cc) BY-NC 
capitalist society." 22 Having said this, the intrinsic dialectics of art's truth content can serve as a dynamic foundation to keenly reflect social illness. In the words of Adorno, "It is from within, in the movement of the immanent from of artworks and the dynamic of their relation to the concept of art, that it ultimately becomes manifest how much art-in spite of and because of its monadological essence-is an element in the movement of spirit and of social reality." 23

Simultaneous to art's composition of providing site for the dialectical relation of society's polar opposites is its capability of self-reflexivity. Equipped with this ability, it is but an imperative to itself to revaluate its own content incessantly. This is a rumination of objective reality, culture, and society, including its role within the historical whole. In this process of selfunderstanding, it must be able to recognize its critical position within the social whole, especially with regard to different contingencies and dominations.

An artworks' concretization of critique is through the configuration of its materials that are socially and dialectically conditioned. In this manner, art transforms into a critical participation in the social totality which it diagnoses. Infused with the ability to articulate the damaged life, as Adorno asserts, an artwork pertaining to a utopia amidst social chaos is like a Disneyland reality simulating our perception of the world. In the same vein, it is but a monstrosity to manage drinking a luscious wine when the stomachs and the souls of the people in the neighborhood are in ominous poverty. This misguided consciousness found in both scenarios is currently parallel to the administered false needs propagated by the capitalist system so as to effectively numb the people's consciousness. ${ }^{24}$ Therefore, a radicalized aesthetic theory today must not only include what is pleasing, but more importantly, must also highlight the obverse of what is usually pleasing - the abject or the negative.

Contradictions, from Adorno's unwavering critique of rationality's pathological hubris, are reconfigured by him as the vital fuel of dialectical thinking both in the society and the artwork. Since contradictions cannot be entirely exterminated on both aforesaid locations, the particularities of human experience that engender them may lead us to an understanding of the non-identical character of human experience. Because truth and human intentions are dialectically-related, the unity of truth embedded within the non-identical's differential corpus can aid human intentions in salvaging

22 Zuidervaart, Adorno's Aesthetic Theory, 51.

${ }^{23}$ Adorno, Aesthetic Theory, 254.

${ }^{24}$ Cf. Herbert Marcuse, One-Dimensional Man: Studies in the Ideology of Advanced Industrial Society (Boston: Beacon Press Boston, 1964), 5.

(C) 2014 Raniel SM. Reyes

http://www.kritike.org/journal/issue 14/reyes june2014.pdf

ISSN 1908-7330 
nature from the manacles of instrumental reason and advanced capitalism. ${ }^{25}$ Since the dialectic is the "ontology of the wrong state of things," 26 according to him, it can offer conceptual possibilities, outside the bounds of identitarian thinking and the capitalist system, or any epistemological and social system. For the reason that the culture industry has debased art's cognitive, historical, and critical constitutions through commodification and reification, it is through the artwork's disclosure of the wrong state of things (the suffering individuals, the corrupted society, the unjust social systems, etc.) - a reality concealed to us by capitalism via different social illusions, that art's critical and emancipatory power can be recuperated.

\section{Cruz's Installation as the Personification of the Ugly}

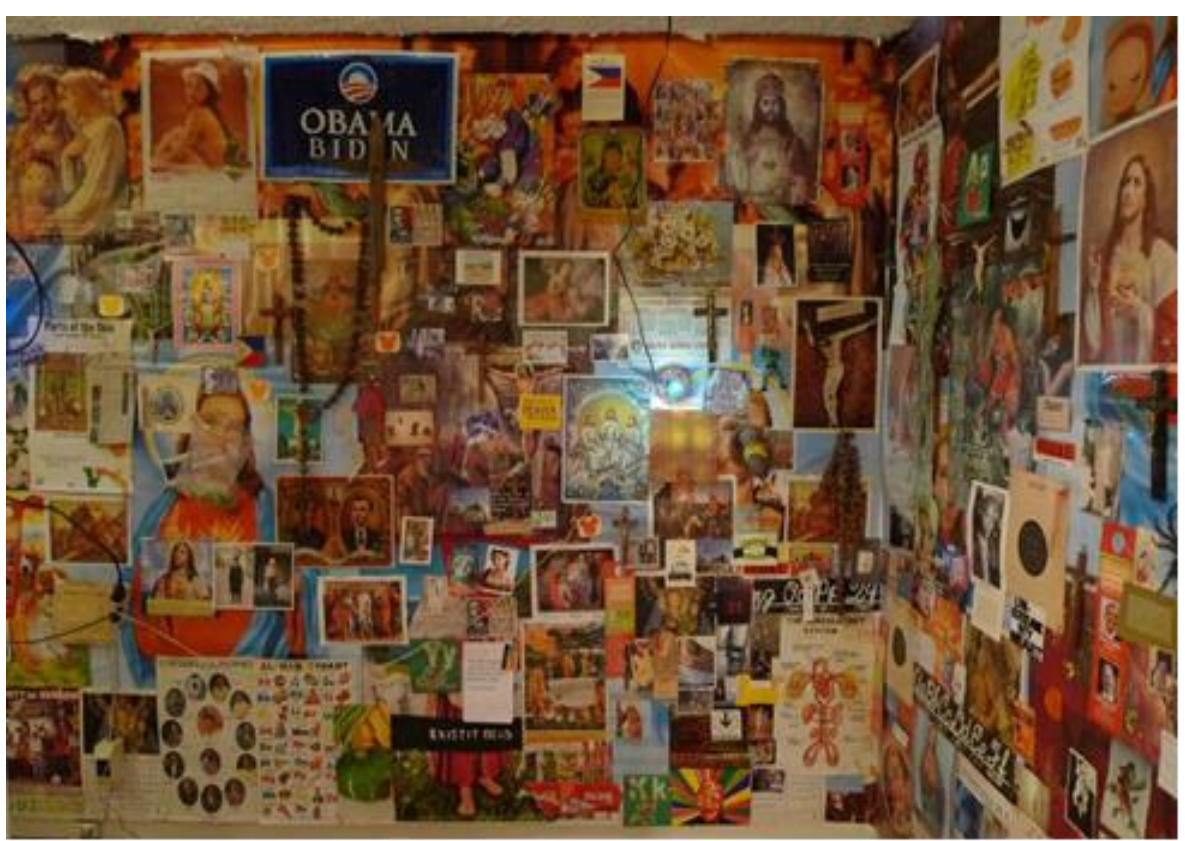

Figure 3: "Poleteismo" by Mideo M. Cruz ${ }^{27}$

In the year 2012, the eccentric artist Mideo Cruz, identified for his frequent insolent exhibitions, authored one of the most disquieting controversies in the history of Philippine visual arts. His mixed-media collage entitled, "Poleteismo" (Polytheism) showcased at the Cultural Center of the Philippines (CCP), bothered and infuriated many Filipinos, particularly

${ }^{25}$ Adorno, Negative Dialectics, 294.

${ }^{26}$ Ibid., 11.

${ }_{27}$ Kulo (Cultural Center of the Philippines). Digital Image, in <http://www.facebook.com/photo.mideocruz/php?10150331333391350>, 5 August 2011. 
various conservative groups and traditional politicians. Many critics have been in extreme ire as to accuse Cruz's works as blasphemous and sacrilegious. This is premised on the images of Christ and Mary alongside a condom and religious figures near wooden phallic symbols. The installation also includes a landscape of different consumerist and subversive illustrations like white mythology symbols, as well as political dissent against traditional politicians and entertainment celebrities in the Philippine society. Unfortunately, the picture of Christ with a penis on the forehead has been detached from its socio-aesthetic context by the media and was misinterpreted as the centerpiece of the artwork. The unwarranted reproduction of this prejudicial image rendered the media stations increased profit and aggravated the on-going indictment against Cruz.

Amidst the heated debates surrounding the issues of irreverence, freedom of expression and censorship, among others, Cruz says in one of the interviews:

My work never goes out of the way to offend. But I do like to provoke debate and critical thinking. Art is a way of expressing one's views about the world, culture, and history, and this is what I do in my work. The audience is free to make their own conclusion and interpretation about the images I create, but I must confess I didn't expect anyone to react so violently against 'Poleteismo' . .. which loosely translates into 'many beliefs' or 'many deities.' Throughout history, humanity has grown to create new gods and these are not always religious figures but concepts and objects. Some have taken to worshipping money; some see politicians as godsend. People create idols and these idols whether or not they're deserving of idolatry ... affect our lives and how we function and see the world. ${ }^{28}$

However, regardless of the affirmative intention of Cruz, efforts by the media to sensationalize the issue have already exacerbated the situation. And the liberating discourse behind his artwork was superseded by the prevailing conservative pole in the Philippine society-the Church. ${ }^{29}$ When

${ }^{28}$ See this interview in the internet article of Ina Silverio, "Mideo Cruz 'Poleteismo' continues to stir debate," in Bulatlat (17 August 2011), <http://bulatlat.com/main/2011/08/17/ mideo-cruz-poleteismo>.

${ }^{29}$ The Senate committee investigated in aid of legislation the controversial exhibit in the $\mathrm{CCP}$, which showed some of Cruz's art work. The exhibit shocked various groups who labeled Cruz's art pieces "sacrilegious and blasphemous." At the start of the Senate hearing, 
the said exhibition was closed due to the pressures coming from various groups, Ms. Karen Flores, the visual arts head of CCP resigned-lamenting that religion should not lead people into hatred, but rather, should enlighten the people "to practice tolerance amid our differences." 30

The reaction of majority of Filipinos was of disgust towards the installation art, whose critical import they could not decipher. They failed to be moved by the existential and affirmative message it offered. I suppose none of the critics even bothered to ruminate on the important socio-historical configuration of "Poleteismo." 31 Although Cruz's artwork came into Philippine perception in a radically dissident force, this can be relatively paralled to the critico-historical imports revealed to us by Juan Luna's Spoiliarium (painting), Jose Rizal's Noli Me Tangere (literature), Epifanio San Juan's Writing and National Liberation (literature), and Ismael Bernal's Manila by Night (film); or even in Henry David Thoreau's On the Duty of Civil Disobedience (literature), Edward Said's Orientalism (literature), and Roman Polanski's The Pianists (film).

Miserably, a cultural amnesia obscures the historical awareness of the Filipino people causing them to become oblivious or repugnant to the aesthetic medium and life-force used by these artist-thinkers for the conveyance of their redemptive messages. Their critical consciousness is already adulterated by advanced capitalism, as art for them has turned into none other than a fetishized product-devoid of any cultural and historical values, be it in communal dynamics or in nation-building. They failed to determine that this negatively dialectical component of art is the most potent power to embattle the various self-mutating camouflages of capitalism and descending life, like what is creatively and unnervingly presented in Cruz's installation. Art as a tool for pedagogy, reflection, and critique, is something

Senator Edgardo Angara (chairman of the Senate committee on education, arts, and culture) said the inquiry is not a trial but a venue to listen to the views and opinions on this very important and sensitive topic. Despite Cruz's absence in the investigation, he asserted in an interview that "I abide with the decisions of a broad alliance that I am closely working with, in advancing this cause instead of feeding my self-serving impulse to defend my work or my person to each query, insult or threat being hurled at me. After all, the purpose of my artworks has always been to instill critical thought more than in selling my name." See David Dizon, "Mideo Cruz snubs Senate probe, risks subpoena," in ABS-CBN News (11 August 2011), <http://www.abscbnnews.com/nation/08/16/11/mideo-cruz-absent-senate-probe>.

30 Julie Aurelio, "Artists protest censorship," in Inquirer (11 August 2011), <http://globalnation.inquirer.net/8703/artists-protest-censorship>, 11 August 2011.

${ }^{31}$ Many famous Philippine personalities have blatantly expressed their derision to Cruz's installations. In the conservative realm, Oscar Cruz (former Dagupan Archbishop) described "Poleteismo" as "sick and sickening," while Etta Rosales (chairperson of the Commission on Human Rights) illustrated it as the "product of a troubled mind." Joining the fray, politicians like Imelda Marcos, Amado Bagatsing, Jinggoy Estrada and Tito Sotto muddled the issue in irreverent and religious vocabularies. See Ibid.

(c) 2014 Raniel SM. Reyes

http://www.kritike.org/journal/issue 14/reyes june2014.pdf

ISSN 1908-7330

$(\mathrm{cc}) \mathrm{BY}-\mathrm{NC}$ 
that Filipinos, especially those disdainful of the installation, are still ignorant about. Of course, we must be reminded that this event is roughly similar to the challenge faced by Adorno's aesthetic theory in confronting the dialectic of enlightenment and the aggravating capitalism of his time.

Undeniably, a consumerist viz. decadent society - a life of the false, is opened to us via the said installation. In the words of Adorno, "Society's discontinuities, its untruth and ideologies emerge in the muddled work as structural discontinuities, as deficiencies." 32 Cruz's dialectically negative artwork has personified the ugly facet of the Philippine society, where capitalist values, imperialized relations, popular culture, and demagogic politics achieve a commanding sovereignty over the Filipino every day. Sadly, he was untimely for the contemporary Filipino sensibilities-analogous to a Goethe or a Nietzsche. But despite this conundrum, it has started to make a resonating intensity in the molecular level of Philippine culture because "artworks immolate themselves through the temporal nucleus, devote their own life to the instant of the appearance of truth, and tracelessly vanish without thereby diminishing themselves in the slightest." 33

\section{The Possibility of Emancipation and Philosophy's Education}

Despite the death of the aura brought about by the onslaught of the culture industry, Benjamin remains relatively optimistic. For him, notwithstanding the enormous mechanical reproduction of art, it has the power to broaden our cognitive field and, dialectically, we create new spaces for critical thought. ${ }^{34}$ However, Adorno points out that Benjamin's positive outlook would only materialize after our realization of our place and role within the capitalist system. It is because our immersion to the capitalist way of life exposes us to the inherent contradictions in its oppressive machinery, thereby conditioning our critical acumen. In fact, a peculiar brand of contradiction is derivable from the inner operations of this system. It is a contradiction where human subjectivity is totalized by the mechanism of capitalist production. Hence, the tension emerges between the domineering requirements of advanced capitalism and the pursuit of the individual to achieve self-realization both in society, in culture, and in the artwork. This so-

${ }^{32}$ Adorno, Aesthetic Theory, 395.

33 Ibid., 234

34 Although Benjamin remains relatively optimistic regarding the mechanical reproducibility of photography and film due to its capacity to educate the masses, Adorno is very critical against it. For him, this brand of production enabled photography and film to be absorbed by the domineering power of the capitalist system, thereby numbing their ability to foster collective emancipation. See Jarvis, Adorno: A Critical Introduction, 30.

(C) 2014 Raniel SM. Reyes

http://www.kritike.org/journal/issue 14/reyes june2014.pdf

ISSN 1908-7330

$(\mathrm{cc})$ BY-NC 


\section{ADORNO ON AESTHETICS}

called artificial conflict imposed by the culture industry to society and culture can only be critically confronted via art's disclosure of the wrong state of things.

This kind of immanent critique, undoubtedly, was boldly instigated by Cruz despite widespread hostilities and controversies. If the purpose of Cruz's installation is to shock, then it responds fairly to Adorno's hope for the critical substance of art. Firstly, the installation defies traditional artwork categories in terms of materials, assemblage-techniques, and appearance. This affirmative violation of art conventions point to the idea that the immanent dynamicity and criticality of traditional crafts are already subsumed under the structure of the culture industry. ${ }^{35}$ Secondly, the shock effect stimulated by the artwork is indicative of the wrong state of things in the Philippine society. Thirdly, the form is itself a demonstration of shock, i.e., of straightforward comprehensibility and logicality. And lastly, shock should elevate our critical outlook, not only of art, but also the content of the artwork. Meaningfully, through this radical force, we are led to the much profounder depth of his aesthetic biosphere. It is a community that accentuates the role of the artist in our life, which is not merely to enrich the people's understanding and experience of art; but more importantly, to free the people's minds from the fetters of reified and regressive thinking, and feudal relations by utilizing the critical dialectics intrinsic in art.

By showing us the false, an artwork, then, could open up possibilities. The false here and now points to a possible beyond. Fuelled by the negative dialectics, it can transgress the canvass' territoriality and can materially illustrate to us the panorama of a changeable world. Since art can disclose the wrong state of things, it is constitutive of a driving force of presenting with perspicacity the disjointed and obscure whole. An aesthetic theory then becomes critical by negating social malaises fashioned under the capitalist system in the likes of injustice, narcissism, and reified consciousness. As such, a notion of emancipation must always be negative. Significantly, this characteristic helps us to overcome the internally contradictory conditions and fuels its antagonistic distance towards society subjugated by identity and capitalism. ${ }^{36}$ By going against the grain of the present, art opens us a future horizon of hope. Compellingly, Benjamin is correct in saying that "it is only for the sake of those without hope that hope is given to us." ${ }^{37}$

\footnotetext{
${ }^{35}$ Consequently, protesters have accused his work of relativism, which entails not only a violation of universal standards of arts, but also of morality. But looking at the other side of the coin, this resistance also means the numbing of their critical acuity, thanks to capitalism.

${ }^{36}$ Cf. Paolo Bolaños, "The Critical Role of Art: Adorno between Utopia and Dystopia," in Kritike, 1:1 (2007), 26.

37 This last sentence in Marcuse's One-Dimensional Man is a statement from Benjamin. See Herbert Marcuse, One-Dimensional Man: Studies in the Ideology of Advanced Industrial Society, 257.

(c) 2014 Raniel SM. Reyes

http://www.kritike.org/journal/issue 14/reyes june2014.pdf

ISSN 1908-7330
}

(cc) BY-NC 
In the case of philosophy, if it desires to be relevant today, then it must become art-like. This means philosophy must be more receptive to materiality, exteriority and self-revaluation. Also, it must be both informed by the damaged life and must perpetually expose society's internal incongruities without resorting to teleology. According to Adorno: "If philosophy is still necessary, it is so only in the view that it has been from time immemorial: as critique, as resistance to the expanding heteronomy, even if only as thought's powerlessness attempts to remain its own master and to convict untruth, by their own criteria, both of a fabricated mythology and a convincing, resigned acquiescence on the other of untruth." 38 Being a perennial offshoot of dialectical and historical struggles, philosophy must then be able to articulate life as lived, contrary to the reified reality presented to us by advanced capitalism.

Lastly, philosophy must artistically learn how to fashion new radical and untimely concepts that would help explain and examine the spirit of the times, as Gilles Deleuze and Felix Guattari suggest. ${ }^{39}$ Like the self-evolving capitalist machinery, it must learn to be more fluid without forgetting the specters of identity or dogmatism. Indispensably, philosophy must once more reconfigure its very language so as to become profoundly creative in incessantly regulating the dialectic between the subject and the object, as well as in letting the objects of nature communicate. For it is only in these differential pathways that our mimetic relation with nature (previously corrupted by identity thinking and the culture industry) can be recovered and revitalized. Ultimately, philosophy must become non-philosophical to regain its aesthetic dignity.

Department of Philosophy, University of Santo Tomas, Philippines

\section{References}

Adorno, Theodor and Horkheimer, Max, Dialectic of Enlightenment, trans. by John Cumming (London: Verso, 1997).

Adorno, Theodor, Aesthetic Theory, trans. by Robert Hullot-Kentor (London: Continuum, 2004).

Minima Moralia: Reflections on a Damaged Life, trans. by E. F. N. Jephcott (London: Verso, 2005).

Negative Dialectics, trans. by E. B. Ashton (London: Routledge, 1973).

38 Theodor Adorno, "Why Still Philosophy?," in Critical Models: Interventions and Catchwords, trans. by Henry Pickford (New York: Columbia University Press, 1998), 6.

${ }^{39}$ Cf. Gilles Deleuze, and Felix Guattari, What is Philosophy?, trans. by Hugh Tomlinson and Graham Burchell (New York: Columbia University Press, 1994).

(C) 2014 Raniel SM. Reyes

http://www.kritike.org/journal/issue 14/reyes june2014.pdf

ISSN 1908-7330

$(\mathrm{Cc}) \mathrm{BY}^{\mathrm{B}-\mathrm{NC}}$ 
Notes to Literature, Vol. II, trans. by Shierry Weber (New York: Columbia University Press). The Culture Industry (London: Routledge, 1991). "Why Still Philosophy," Critical Models: Interventions and Catchwords, trans. by Henry Pickford (New York: Columbia University Press, 1998).

Aurelio, Julie, "Artists protest censorship," in Inquirer (11 August 2011), $<$ http://globalnation.inquirer.net/8703/artists-protest-censorship>.

Benjamin, Walter, "The Work of Art in the Age of Mechanical Reproduction," Illuminations: Essays and Reflections, trans. by Harry Zohn and ed. by Hannah Arendt (New York: Schocken Books, 2007).

Bolaños, Paolo, "The Critical Role of Art: Adorno between Utopia and Dystopia," Kritike: An On-line Journal in Philosophy, 1:1 (June 2007), 25-31.

Bresson, Robert, Notes on the Cinematographer, trans. by Jonathan Griffin (London: Quartet, 1986).

Colgate - Mona Lisa - "Smile Big! Exhibit those pearly whites." Digital Image, $450 \times 225$, in <http://www.coroflot.com/bettinna/Advertising1>, 12 April 2007.

Cruz, Mideo, "Poleteismo," in Kulo (Cultural Center of the Philippines), Digital Image, in <http://www.facebook.com/photo.mideocruz/ php?10150331333391350>, 5 August 2011.

Deleuze, Gilles and Guattari, Felix, What is Philosophy?, trans. by Hugh Tomlinson and Graham Burchell (New York: Columbia University Press, 1994).

Dizon, David, "Mideo Cruz snubs Senate probe, risks subpoena," in ABSCBN News, < http://www.abs-cbnnews.com/nation/08/16/11/mideocruz-absent-senate-probe $>, 11$ August 2011.

Huhn, Thomas ed., The Cambridge Companion to Adorno (Cambridge: Cambridge University Press, 2004).

Jarvis, Simon, Adorno: A Critical Introduction (Cambridge: Polity Press, 1998). Marcuse, Herbert, One-Dimensional Man: Studies in the Ideology of Advanced Industrial Society (Boston: Beacon Press, 1964).

Necosia, Marcelino, "The Unseen World," Digital Image. Soil on canvass), in Talaandig School of Living Tradition Soil Paintings, $<$ http://www.facebook.com/photo.php?fbid=166653023354019>, 22 April 2007.

Silverio, Ina, "Mideo Cruz "Poleteismo" continues to stir debate," in Bulatlat $<$ http://bulatlat.com/main/mideo-cruz-poleteismo>, 17 August 2011.

Wilson, Ross, Theodor Adorno: Routledge Critical Thinkers (New York: Routledge, 2007).

Witkin, Robert, Adorno on Popular Culture (New York: Routledge, 2003).

(c) 2014 Raniel SM. Reyes

http://www.kritike.org/journal/issue 14/reyes june2014.pdf

ISSN 1908-7330

$(\mathrm{cc}) \mathrm{BY}-\mathrm{NC}$ 
Zuidervaart, Lambert, Adorno's Aesthetic Theory: the Redemption of Illusion (Massachusetts: MIT Press, 1994). 